Удк $616-053.9$ - 083

\title{
ОСОБЛИВОСТІ ОРГАНІЗАЦІЇ СЕСТРИНСЬКОЇ ДОПОМОГИ ОСОБАМ СТАРШОГО ВІКУ
}

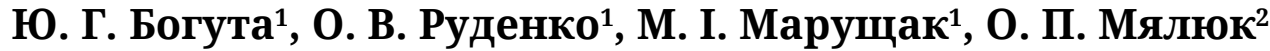 \\ ${ }^{1}$ ДВНЗ «Тернопільський державний медичний університет \\ імені І. Я. Горбачевського МОЗ Украӥни” \\ ${ }^{2}$ Рівненський державний базовий медичний коледж
}

\begin{abstract}
У статті наведено особливості організації сестринської допомоги особам старшого віку. Показано, що вирішити завдання зміцнення здоров'я населення, вдосконалення роботи установ вітчизняної охорони здоров'я в нових економічних умовах неможливо без підвищення ролі сестринського персоналу найчисельнішої ланки медичних працівників. Неможливо також забезпечити потреби суспільства в якісній медичній допомозі без зміни статусу медсестри, розширення сфери ії професійної діяльності, раціонального розподілу обов’язків між лікарями та медсестрами. Разом із тим, перетворення в сестринській справі не можуть здійснюватися без аналізу сучасного стану сестринської допомоги, без чіткого визначення як сильних, так і слабких сторін діяльності медсестер. Отже, сучасна практика сестринського обслуговування перебуває в стадії системних перетворень та потребує наукового обгрунтування, оскільки незбалансованість медичних кадрів, малоефективне використання сестринського персоналу в практиці негативно впливає на якість медичної допомоги.
\end{abstract}

\section{FEATURES OF NURSING CARE ORGANISATION FOR OLDER PERSONS}

\author{
Y. G. Boguta ${ }^{1}$, O. V. Rudenkoㄹ, M. I. Marushchak ${ }^{1}$, O. P. Mialiuk ${ }^{2}$ \\ ${ }^{1}$ I. Horbachevsky Ternopil State Madical University \\ ${ }^{2}$ Rivne State Basic Medical College
}

\begin{abstract}
The article presents the features of nursing care of older persons. It is shown that solving the problem of promoting health, improvement of national health institutions in the new economic conditions is impossible without increasing the role of nursing staff - the largest part of medical workers. It is unable to provide society's needs for quality medical care without changing the status of nurse's expansion of its professional activities, rational division of responsibilities between doctors and nurses. However, the transformation in nursing care can't be implemented without an analysis of the current state of nursing care, without a clear definition as strengths and weaknesses of nurses' work. Thus, the current practice of nursing service is in the process of systemic change and requires scientific justification because medical personnel imbalance, inefficient use of nursing staff in the practice affects the quality of care.
\end{abstract}

Вступ. У II половині XX століття істотно змінилася вікова структура населення, яка визначається рівнем народжуваності та смертності, а також зумовлює частку економічно активного населення, ступінь забезпеченості країни трудовими ресурсами. Чисельність населення похилого віку планети з 1950 р. зросла в 5 разів [1].

На даному етапі не має однозначної думки щодо визначення того, який саме вік називати похилим. Наприклад, в Американську асоціацію пенсіонерів, яка проголошує себе захисниками людей похилого віку, приймають всіх старше п'ятдесяти. Європейське регіональне бюро геронтологів Всесвітньої організації охорони здоров'я в 1963 р. вважає похилим віком у () Ю. Г. Богута, О. В. Руденко, М. І. Марущак, О. П. Мялюк, 2017 чоловіків період від 60 років до 74, а у жінок з 55 до 74 років, з 75 років настає старість. А. В. Мудрик виділяє період похилого віку з 50 до 60 р. [2], далі старість 60-70 років і, починаючи з сімдесятирічного віку, довгожительство. Деякі автори приймають за нижню межу похилого віку час виходу на пенсію (55-65 років), інші пропонують використовувати як показник похилого віку наповненість людського життя (наявність подій, характерних саме для даного періоду). Більшість дослідників згодна з виділенням вікової кризи в період 60-65 років. У даний час загальновизнано, що старість - це тривалий період, повноцінний етап розвитку, такий же, як молодість або зрілість, який має свої вікові завдання і можливості самоактуалізації. 
У всьому світі зростає інтерес до проблем похилого та старечого віку. За прогнозами ООН, найближчим часом на землі буде налічуватися понад 125 млн людей старших вікових груп, причому самим разючим стане зростання чисельності осіб віком 80 років і старших. Ця прогнозована демографічна ситуація диктує необхідність розвитку геріатрії [3].

Збільшення в складі населення осіб похилого віку свідчить не тільки про постаріння населення (зниження народжуваності, значне зменшення кількості працездатного населення), але ставить перед органами та установами охорони здоров'я, праці та соціального розвитку, Пенсійного фонду ряд серйозних завдань з організації медико-соціальної допомоги людям похилого та старечого віку [4-9].

Важливо поєднати соціальний захист і медичну допомогу особам похилого віку в єдину систему медико-соціального захисту. Завдання консолідації всіх фахівців, вчених і практиків у галузі геронтології та геріатрії стають цілком очевидними і нагальними так само, як і налагодження зв'язків між фахівцями і науковцями, які працюють в цій галузі [10].

Основна частина. Вікові зміни є визначальними факторами розвитку патологічних відхилень і хронічних захворювань $[11,12]$. У той же час у численних дослідженнях було показано, що соціально-економічні умови значною мірою визначають відмінності у здоров'ї: кращі умови, як правило, пов'язані з кращими оцінками здоров'я і навпаки $[13,14]$. Одним із проявів формування хронічної патології населення, особливо в старшому віці, є комплексність, поєднання захворювань, що вражають різні органи і системи. У цьому випадку розвиток патологічних змін у будь-якій системі порушує збалансованість їх взаємопов'язаного функціонування і $є$ фоном розвитку інших видів патології.

Поєднання захворювань, або коморбідність, - це комбінація кількох хронічних захворювань. Статистичні дані про ці комбінації дуже важливі для забезпечення медичної допомоги та управління охороною здоров'я, особливо в умовах постаріння населення [15-17]. До 70-80 \% пенсіонерів потребують медикосоціальної допомоги, у них по 4-5 хронічних захворювань. Отже, з року в рік зростатимуть витрати на їх обслуговування. Це зумовлює нагальну необхідність у вивченні стану організації медико-соціальної допомоги громадянам пенсійного віку [18].

У рамках програми вдосконалення якості медичної допомоги досить багато уваги приділяється питан- ням поліпшення якості лікарської допомоги. Однак вирішити завдання зміцнення здоров'я населення, вдосконалення роботи установ вітчизняної охорони здоров'я в нових економічних умовах неможливо без підвищення ролі сестринського персоналу - найчисельнішої ланки медичних працівників. Неможливо також забезпечити потреби суспільства в якісній медичній допомозі без зміни статусу медсестри, розширення сфери її професійної діяльності, раціонального розподілу обов'язків між лікарями та медсестрами. Разом із тим, перетворення в сестринській справі не можуть здійснюватися без аналізу сучасного стану сестринської допомоги, без чіткого визначення як сильних, так і слабких сторін діяльності медсестер. У зв'язку з цим, важливу науково-практичну значимість набувають дослідження, спрямовані на вироблення спеціальних методів оцінки якості та управління сестринською допомогою [19-22]. Світова практика показала, що раціональне використання сестринських кадрів приводить до значного поліпшення якості й доступності медичної допомоги [23-25].

У даний час майже всюди відбувається процес переоцінки всієї системи сестринського обслуговування. у багатьох розвинених країнах сучасна система сестринського обслуговування розглядається як окрема галузь медицини, яка доповнює інші сфери медичної діяльності в рамках багатопрофільної бригади [26-28]. У нашій країні сестринський персонал працює переважно під керівництвом лікарів і допомагає швидше іншим медичним працівникам, ніж самим пацієнтам, що $\epsilon$ суттєвою перешкодою для розвитку функцій сестринського персоналу. Ситуацію ускладнюють відсутність відповідної підготовки, низький статус і погані умови праці в поєднанні з великою кількістю робочих годин і низькою оплатою праці $[29,30]$.

Догляд за пацієнтом (фізичний), який є одним 3 елементів сестринської діяльності, дотепер вивчали з позицій розвитку сестринської справи 20-30-річної давності і часто розглядали як щось другорядне в лікувальному процесі, що входить в обов'язки санітарок. Однак реформи в сестринській справі приводять до перегляду багатьох сформованих стереотипів. Зокрема вони передбачають організацію діяльності сестринських служб на науковій основі, розширення обсягу сестринської діяльності в бік їі більшої самостійності, створення установ медико-соціальної спрямованості, де головним є фізичний і психологічний догляд за пацієнтами. Професійно виконаний фізичний i психологічний догляд створює основу для успішної 
медикаментозної терапії. Однак потрібно визнати, що для реформування сестринської справи необхідно створити нові поняття, визначення та термінологію в сестринській діяльності, включаючи фізичний догляд за пацієнтами. У нашій країні найбільш поширена двоступенева система медичного обслуговування стаціонарного хворого. В основному це пов'язано з неукомплектованістю медичних установ кадрами молодшого медичного персоналу [31]. У зарубіжних країнах шукають можливості поліпшити цю ситуацію, в США по догляду за хворими після невеликого навчання допускають родичів пацієнта [32-35]. Необхідно відзначити, що у вітчизняній охороні здоров'я тенденція передачі догляду за пацієнтом повністю в руки медичної сестри відчувається дуже гостро. Ускладнює становище той факт, що праця середнього і молодшого медичного персоналу абсолютно не механізовані, в той час як відзначається збільшення внутрішньолікарняних переміщень хворих. За кордоном використовується безліч транспортних засобів: візків, каталок та ін. В Англії розроблено спеціальне пристосування «механічні руки», що допомагає перевернути хворого в ліжку. У США випускаються підйомники для пацієнтів, які приймають ванну. В Швеції налагодили виробництво одноразових суден. У 2004 р. в одній з японських клінік пройшов випробування робот, який пересувається на коліщатках і розносить по поверхах документи, рентгенівські знімки, історії хвороби, що дає можливість медичній сестрі більше часу приділяти догляду за пацієнтом [36-39]. У лікувальних установах роботу, яка потребує професійної сестринської кваліфікації, повинні виконувати санітарки, яких у вітчизняних медичних установах катастрофічно не вистачає. Не можна не визнати, що у вітчизняній охороні здоров'я дотепер догляд за пацієнтом, який здійснюється медичною сестрою, не відрізняється від догляду, який виконує молодша медична сестра. А тим часом у країнах Європи і Америки ще в минулому столітті робота медсестри була переведена на наукову основу. Провідні принципи сестринського догляду за пацієнтом розробив В. Хендерсон. Вони вимагають від медичної сестри не автоматичного виконання призначень лікаря, а осмисленого ведення сестринського процесу, який при необхідності вона може регулювати. Дані принципи впроваджені в роботу сестринських служб в Європі та Америці [40-43].

Протягом останніх десятиліть у країні сестринській справі не приділяли належної уваги, що призвело до значного відставання в цій галузі охорони здоров'я від розвитку сучасної науки і медицини. Це послугувало причиною вибування з професії кваліфікованого сестринського персоналу, зниження забезпеченості медичних установ сестринськими кадрами, збільшення дисбалансу в співвідношенні лікар і медична сестра i, як наслідок, стало причиною погіршення якості наданої медичної допомоги [44, 45]. Система охорони здоров'я в цілому страждає від незбалансованості медичних кадрів, малоефективного використання сестринського персоналу в практиці, що робить істотний вплив на якість медичної допомоги.

Медичні сестри - одна з найбільш численних груп медичних працівників, вони традиційно відіграють значну роль в системі суспільної охорони здоров'я. у багатьох випадках саме медсестра є ланкою між населенням і системою охорони здоров'я [29, 46, 47]. Без зміни статусу медичної сестри, розширення сфери її професійної діяльності та раціонального перерозподілу обов'язків між лікарями та середніми медичними працівниками неможливо задовольнити потреби суспільства в якісній медичній допомозі [48-50]. Робота середнього медичного персоналу в закладах, які надають медичну допомогу людям похилого віку, відрізняється від видів робіт в інших медичних установах. Організація роботи з геріатричними пацієнтами вимагає від медичної сестри вміння: кваліфіковано оцінювати стан пацієнта; складати план роботи з конкретним пацієнтом; виявляти ініціативу в призначенні пацієнтові обстеження того чи іншого виду; організовувати роботу всіх ланок надання допомоги пацієнту; взаємодіяти з соціальними службами та громадськими організаціями.

У пацієнтів похилого віку проблеми досить часто чергуються і змінюються, отже, в комплексному лікуванні пацієнтів старшого віку особливу увагу слід приділяти питанням сестринського доглядута його документування. У зв'язку з наявністю в осіб похилого та старечого віку множинної, поєднаної патології зростає кількість лабораторних аналізів, УЗД та рентгенологічних досліджень, що також впливає на навантаження медичної сестри $[3,51]$.

При наданні допомоги цим пацієнтам важливо дотримуватися принципу послідовності і безперервності надання медичної та соціальної допомоги. Оцінка медичною сестрою при госпіталізації пацієнта його здатності до самообслуговування, оцінка пам'яті й інших індивідуальних особливостей сприяє виробленню адекватної тактики ведення хворого. Стандартизація форми запису дозволяє легко спосте- 
рігати динаміку стану пацієнта всім членам медичної бригади. Практика роботи в геріатричних закладах показала необхідність зв'язку медичного працівника з соціальною службою та родичами для поліпшення якості життя пацієнта [6].

По сьогодні не розроблено систему оцінки якості сестринської допомоги. Відсутні критерії якості медсестри. У медичних організаціях розробляються і впроваджуються різні варіанти контролю якості роботи середнього медперсоналу, але немає науково обґрунтованої методики експертної оцінки, відсутні затверджені стандарти сестринської діяльності [52, 53]. Більшість медсестер відчуває брак знань в галузі психології старіння і соціально-психологічної адаптації пацієнтів, раціонального харчування осіб похилого та старечого віку, геріатрії, недостатньо володіють методами їх активізації [3]. Крім сумлінного виконання функціональних обов'язків вона повинна професійно вдосконалюватися. Медсестра повинна володіти відповідними знаннями, вміннями, а також уважністю, відповідальністю, співчуттям, добротою, жалістю, доброзичливістю, повагою до особистості, умінням вислухати, дбайливістю, упевненістю, самокритичністю, привітністю (якості визначені в результаті порівняння

\section{СПИСОК ЛІТЕРАТУРИ}

1. Альперович В. Д. Социальная геронтология / В. Д. Альперович. - Ростов-на-Дону : Феникс, 1997. - 557 с.

2. Мудрик А. В. Введение в социальную педагогику : учебное пособие для студентов / А. В. Мудрик. - М. : Институт практической психологии, 1997. - 365 с.

3. Гешева Ф. В. Особенности деятельности стационарного отделения госпиталя за четыре года / Ф.В.Гешева // Геронтология: место и роль медико-социальных проблем пожилых в КБР, пути решения : сборник тезисов докладов Первой республиканской научно-практической конференции. - Нальчик, 2003. - С. 21-27.

4. Борисенко О. В. Оценка эффективности методов скрининга / О. В. Борисенко // Заместитель главного врача. - 2011. - № 3 (58). - С. 22-29.

5. Бровкин С. В. Опыт работы МУЗ «Дом сестринского ухода» г. Петрозаводска / С. В. Бровкин, Л. Н. Иванова // Главная медицинская сестра. - 2005. - № 6. - С. 13-27.

6. Пушкова Э. С. Модель работы медицинской сестры в гериатрии / Э. С. Пушкова, Г. М. Подопригора, С. В. Шарин // Клиническая геронтология. - 2005. - Т. 11, № 7. - С. 39-40.

7. Соколин В. Л. Люди счет любят / В. Л. Соколин // Вопросы статистики. - 2008. - № 9. - С. 3-6.

8. Фомина А. В. О деятельности сестринской службы в обеспечении высокотехнологичной медицинской помо- думок пацієнтів, медсестер, лікарів, керівників будинків для людей похилого віку) [54].

Варто зазначити, що здійснення фізичного догляду за хворим, будучи одним із найважливіших розділів сестринської справи, покликане забезпечити створення найсприятливіших умов перебування пацієнта в лікарняному середовищі за допомогою заповнення у нього дефіциту самообслуговування. Однак, на жаль, необхідно визнати, що у вітчизняній охороні здоров'я даний вид сестринської діяльності в даний час не має чітко вираженого визначення та клінічної класифікації, що ускладнює його вивчення [31]. Сучасна практика сестринського обслуговування перебуває в стадії системних перетворень. Розпочато проведення комплексних досліджень з вивчення диференційованого навантаження сестринського персоналу в роботі різних медичних установ [55].

Висновок. Сучасна практика сестринського обслуговування перебуває в стадії системних перетворень та потребує наукового обґрунтування, оскільки незбалансованість медичних кадрів, малоефективне використання сестринського персоналу в практиці негативно впливає на якість медичної допомоги.

щи в регионе / А. В. Фомина, Д. И. Кича, Н. И. Мезенова // Проблемы социальной гигиены, здравоохранения и истории медицины. - 2011. - № 5. - С. 31-33.

9. Царева В. Г. Совершенствование качества сестринской помощи в госпитале ветеранов войн / В. Г. Царева // Медицинская сестра. - 2006. - № 6. - С. 21-22.

10. Бечелов И. Б. Социальная помощь пожилым людям, развитие социальной геронтологии / И. Б. Бечелов // Геронтология: место и роль медико-социальных проблем пожилых в КБР, пути решения : сборник тезисов докладов Первой республиканской научно-практической конференции. - Нальчик, 2003. - С. 8-9.

11. Barba B.E. Recognize the many facets of gerontological nursing / B.E. Barba, A.S. Tesh, E. Kohlenberg // Nurs. Manage. - 2007. - Vol. 38, №1. - P. 36-41.

12. Голубева Е. Ю. Оценка потребности в уходе/обслуживании как ключевая составляющая в планировании услуг для лиц пожилого возраста / Е. Ю. Голубева, Р. И. Данилова // Клиническая геронтология. - 2009. T. 15, № 12. - С. 23-27.

13. Щепин В. О. О перспективах развития сестринского дела на современном этапе развития здравоохранения / В. О. Щепин, Т. Н. Проклова, Т. И. Расторгуева // Бюллетень Национального научно-исследовательского института общественного здоровья. - 2012. - № 1. - С. 160-166. 
14. Canavan M. Palliative care for older people in nursing homes / M. Canavan, D. O'Neill // Irish Med. J. - 2010. Vol. 103, № 6. - P. 165-166.

15. Individuality in older people's care - challenges for the development of nursing and nursing management / R. Suhonen, M. Stolt, M. Puro, H. Leino-Kilpi // J. Nurs. Manag. 2011. - Vol. 19, № 7. - P. 883-896.

16. Relocating care: negotiating nursing skillmix in a mental health unit for older adults / J. Henderson, D. Curren, B. Walter [et al.] // Nurs. Inq. - 2011. - Vol. 18, № 1. - P. 55-65.

17. Молчанова Л. Ф. Статистическая оценка достоверности результатов научных исследований : учебное пособие / Л. Ф. Молчанова, Е. А. Кудрина, М. М. Муравьева. Ижевск, 2004. - 36 с.

18.ГарганееваН.П.Организациямедицинскойпомощив стационаре сестринского ухода: изучение депрессивных расстройств у геронтологических пациентов с сердечно-сосудистыми заболеваниями / Н. П. Гарганеева, Н. И. Шахурова, Е. Д. Счастный // Кардиоваскулярная терапия и профилактика. - 2008. - Т. 7, № 6. - С. 85.

19. Индикаторы оценки качества деятельности сестринского персонала / А. В. Гажева, Н. Н. Камынина, А. С. Лутиков, А. В. Новожилов // Медицинская сестра. 2006. - № 3. - С. 13-15.

20. Новокрещенова И. Г. Организационные подходы к формированию внутриучрежденческой системы управления качеством сестринской помощи / И. Г. Новокрещенова, И. В. Новокрещенов, Н. А. Жихарева // Саратовский научно-медицинский журнал. - 2007. T. 3, № 4. - C. 23-28.

21. Bates-Jensen B. M. Subepidermal moisture is associated with early pressure ulcer damage in nursing home residents with dark skin tones: pilot findings / B. M. Bates-Jensen, H. E. McCreath, V. Pongquan //J. Wound Ostomy Continence Nurs. - 2009. - Vol. 36, № 3. - P. 277-284.

22. Hasson $\mathrm{H}$. A. comparative study of nursing staff, care recipients' and their relatives' perceptions of quality of older people care / H. A. Hasson, J. E. Arnetz // Int. J. Older People Nurs. - 2010. - Vol. 5, № 1. - P. 5-15.

23. Szczerbinska K. Role of method of implementing multi-factorial falls prevention in nursing homes for elderly persons. The EUNESE project / K. Szczerbinska, M. Zak, A. Ziomkiewicz // Aging Clin. Exp. Res. - 2010. - Vol. 22, № 3. - P. 261-269.

24. Dauriac M. C. Nursing assistant in gerontology, a new function / M. C. Dauriac, D. Princiaux // Rev. Infirm. - 2011. № 167. - P. 40.

25. Лоу Р. Роль медсестер в организации ухода за пожилыми людьми: опыт Великобритании / Р. Лоу, Д. Роу // Медицинская сестра. - 2006. - № 3. - С. 34-35.
26. Campbell S. L. The attractiveness of a career in geriatric nursing / S. L. Campbell // J. Gerontol. Nurs. 2010. - Vol. 36, № 6. - P. 3.

27. Clinical update on nursing home medicine / B. J. Messinger-Rapport, D. M. CruzOliver, D. R. Thomas, J. E. Morley // J. Amer. Med. Dir. Assoc. - 2012. - Vol. 13, № 7. - P. 581-594.

28. Jett K. F. The 2009 Doris Schwartz Gerontological Nursing Research Award: Barbara Resnick, PhD, CRNP, FAAN, University of Maryland School of Nursing / K. F. Jett // J. Gerontol. Nurs. - 2009. - Vol. 35, № 4. - P. 8-9.

29. Светличная Т. Г. Новые роли медицинских сестер в общественном секторе здравоохранения / Т. Г. Светличная, Л. П. Лисишникова // Медицинская помощь. - 2005. - № 1. - С. 48-49.

30. Абдулвалеева С. А. Особенности организации сестринского процесса в гериатрической практике / С. А. Абдулвалеева // Сестринское дело и высшее сестринское образование : сборник материалов научно-практической конференции. -Уфа: БГМУ, 2008. С. 136-137.

31. Греков И. Г. Организационно-клинические аспекты сестринского физического ухода в стационарах ЛПУ / И. Г. Греков // Главная медицинская сестра. - 2005. - № 8. - С. 33-46.

32. Aging Issues Nursing Imperatives for Healthcare Reform / C. Beverly, S.G. Burger, M.L. Maas, J.K. Pringle Specht // Nurs. Adm. Q. - 2010. - Vol. 34, № 2. - P. 95-109.

33. Cristofani P. The art of nursing and a context of efficiency: a challenge for the health manager in geriatrics / P. Cristofani // Soins. Gerontol. - 2012. - № 95. - P. 9-11.

34. Mezey M. Specialty Nursing Association Global Vision Statement on Care of Older Adults / M. Mezey // Insight. - 2009. - Vol. 34, № 3. - Р. 22-23.

35. Доклад о состоянии здравоохранения в Европе 2002 г. - Копенгаген, 2002. - 156 с. - (Региональные публикации ВР3, Европейская серия, № 97).

36. Чельцова А. А. Зарубежный опыт стандартизации сестринской деятельности / А. А. Чельцова, Н. Н. Камынина // Медицинская сестра. - 2007. № 8. - C. 20-22.

37. Development of a new prototype for an educational partnership in nursing / M. L. Yeh, J. R. Rong, M. L. Chen [et al.] // J. Nurs. Educ. - 2009. - Vol. 48, № 1. - P. 5-10.

38. Gustafsson C. Supportive leadership in Swedish community night nursing / C. Gustafsson, I. Fagerberg, M. Asp //J. Nurs. Manag. - 2010. - Vol. 18, № 7. - P. 822-831.

39. Knowledge beliefs, attitudes, and self-reported practice concerning urinary incontinence in nursing home care / S. Saxer, R. A. de Bie, T. Dassen, R. J. Halfens // 
J. Wound Ostomy Continence Nurs. - 2009. - Vol. 36, № 5. - P. 539-544.

40. Muller $P$. The development of a personalized nursing care plan for a retired person / P. Muller, M. Sebiane // Soins. Gerontol. - 2009. - № 75. - P. 32-33.

41. Treatment fidelity in nursing home research: the Res-Care Intervention Study / B. Resnick, E. Galik, I. Pretzer-Aboff [et al.] // Res. Gerontol. Nurs. - 2010. Vol. 2, № 1. - P. 30-38.

42. Gadsby R. Death rate of residents with diabetes in nursing homes / R. Gadsby, P. Barker, A. Sinclair // Diabet. Med. - 2012. - Vol. 29, № 6. - P. 829-830.

43. Hassmiller S. Comment on: the Hartford Geriatric Nursing Initiative: developing a focused strategy and strong partnerships to improve nursing care for older adults / S. Hassmiller // Nurs. Outlook. - 2011. - Vol. 59, № 4. - Р. 187-188.

44. Солодухина Д. П. Обеспеченность пожилых пациентов медицинской и социальной помощью в период ремиссии терапевтической патологии / Д. П. Солодухина, Л. Х. Георгиева // Клиническая геронтология. - 2012. - Т. 18, № 5-6. - С. 40-43.

45. Организация медицинского обеспечения больных с патологией системы кровообращения / Т. М. Максимова, Н. П. Лушкина, Е. Е. Борисов, Е. В. Огрызко // Проблемы социальной гигиены, здравоохранения и истории медицины. - 2009. № 1. - С. 32-35.

46. Управление качеством сестринской помощи в лечебно-профилактическом учреждении / И. Г. Новокрещенова, И. В. Новокрещенов, Е. А. Захарова, Н. А. Жихарева // Проблемы социальной гигиены, здравоохранения и истории медицины. - 2008. № 1. - C. 24-26.

47. International collaboration in gerontological nursing / T. A. Touhy, A. Kydd, I. Fagerberg, G. Engstrom // J. Gerontol. Nurs. - 2011. - Vol. 37, № 3. - P. 3-4.
48. Manchester A. Specialist nursing in the community / A. Manchester // Nurs. N. Z. - 2011. - Vol. 17, № 9. - P. 15.

49. Стандартизация сестринских технологий - механизм повышения качества медицинской помощи / Н. М. Попова, К. А. Данилова, М. В. Макарова, О. Ю. Штундер //Экономика здравоохранения. - 2009. № 3. - С. 31-32.

50. Папуцкая Г. И. Качество сестринской помощи / Г. И. Папуцкая // Клиническая геронтология. - 2005. № 7. - С. 47-49.

51. Погодина А. Б. Основы геронтологии и гериатрии : учебник для студентов медицинских училищ и колледжей, слушателей учреждений дополнительного профессионального образования / А. Б. Погодина, А. Х. Газимов. - Уфа, 2004. - 140 с.

52. Фуфаев Е. Н. Оценка качества медицинской помощи на основе стандартов медицинской помощи / Е. Н. Фуфаев // Здравоохранение Российской Федерации. - 2008. - № 4. - С. 28-30.

53. Журавлева Т. П. Сестринское дело в гериатрии : учебное пособие для студентов образовательных учреждений среднего профессионального образования, обучающихся по специальностям медицинского профиля, для студентов медицинских училищ и колледжей / Т. П. Журавлева, Н. А. Пронина. - М. : АНМИ, 2005. - 438 c.

54. Чайкина Н. Н. Социально-гигиеническая характеристика медицинских сестер участковой службы амбулаторно-поликлинических учреждений г. Воронежа, оказывающих медико-социальную помощь лицам старшей возрастной группы / Н. Н. Чайкина // Вестник новых медицинских технологий. - 2011. T. XVIII, № 2. - C. 451-455.

55. Алексеева, В. М. Создание отделения сестринского ухода на базе многопрофильной больницы / В. М. Алексеева, Н. ГШамшурина, А. Н. Подлипенцева // Ремедиум. - 2006. - № 8. - С. 34-36.

Отримано 17.01.17 